\title{
Synthesis, Characterization and Antibacterial Activity of Some New Neocuproine Schiff Bases
}

\author{
Mohammad Habibi Juybari (PhD) \\ Department of Chemistry, Gorgan \\ Branch Islamic Azad University, \\ Gorgan, Iran \\ Hamidreza Pordeli (PhD) \\ Department of Microbiology, Gorgan \\ Branch Islamic Azad University, \\ Gorgan, Iran \\ Saeid Mikaeili (MSc) \\ Department of Microbiology, Gorgan \\ Branch Islamic Azad University, \\ Gorgan, Iran \\ Corresponding author: Mohammad \\ Habibi Juybari \\ Email: m.habibi@gorganiau.ac.ir \\ Tel: $+98-1732160840$ \\ Address: Islamic Azad University, \\ Gorgan Branch, Daneshjoo Avenue, \\ Shahid Kalantari Boulevard, Gorgan, \\ Iran \\ Received: 25 Jul 2018 \\ Revised: 02 Oct 2019 \\ Accepted: 08 Oct 2018 \\ (c) (i) (8) \\ This work is licensed under a Creative \\ Commons Attribution 4.0 License.
}

\begin{abstract}
Background and Objectives: Schiff base ligands are prepared via the condensation reaction of 1,10 - dimethyl-phenantroline aldehyde derivative with some nitrogen donor ligands, such as benzene ring that have different functional groups $(-0 \mathrm{H},-\mathrm{SH}$, $\left.-0 \mathrm{CH}_{3},-\mathrm{CH}_{2} \mathrm{OH},-\mathrm{Br}\right)$ in acetonitrile. Recent studies suggest that Schiff bases might have antibacterial activity. Therefore, we aimed to synthesize new Schiff base complexes and evaluate their antibacterial activity against a number of Gram-positive and Gram-negative bacteria.

Methods: Schiff base ligands and their complexes were characterized by mass spectrometry, infrared spectroscopy and nuclear magnetic resonance spectroscopy. The in vitro antibacterial activity of the Schiff base ligands and metal ions against Staphylococcus aureus, Escherichia coli and Pseudomonas aeruginosa was evaluated by determining minimum inhibitory concentration (MIC) and minimal bactericidal concentration (NBC) using the broth dilution method.

Results: All synthesized Schiff bases exhibited favorable antibacterial activity against the tested microorganism, but the antibacterial effect of compounds $30 \mathrm{H}$ and $3 \mathrm{SH}$ was more significant than that of other compounds.

Conclusion: Compound $3 \mathrm{E} 0 \mathrm{H}$ has favorable antibacterial activity against the tested bacteria.

Keywords: Schiff bases, antibacterial effect, Staphylococcus aureus, Escherichia coli, Pseudomonas aeruginosa.
\end{abstract}




\section{INTRODUCTION}

The design of new Schiff bases with antibacterial properties has received considerable attention over the past several years due to the presence of anions in biological systems and their crucial role in medicinal, catalytic and environmental chemistry $(1,2)$. Schiff bases are amongst the most widely used organic compounds. They are used as pigments and dyes, catalysts, intermediates in organic synthesis, and as polymer stabilizers. They also exhibit a broad range of biological activities, including antifungal, antibacterial, antimalarial, anti-proliferative, antiinflammatory, antiviral, and antipyretic activities $(3,4)$. The first preparation of imines was reported in the $19^{\text {th }}$ century by Schiff. The process involves condensation of a
Carbonyl compound with an amine under azeotropic distillation (Scheme 1).

Scheme 1. Preparation of phenylimino (methyl)-1,10-phenanthrolin derivatives (Schiff based derivatives)

Moreover, molecular sieves are used to completely remove the water formed in the system (4).

The increase in the mortality rate associated with infectious diseases is directly linked to the emergence and spread of drug resistant bacteria (6). Therefore, developing a novel and effective antibacterial agent against such pathogens is urgently needed (7). Schiff bases have been proposed as promising antibacterial agents (8). Therefore, we aimed to synthesize, characterize and assess antibacterial activity of some new neocuproine Schiff bases.

\section{MATERIALS AND METHODS}

We used 2,9-Dimethyl-1,10phenanthroline (neocuproine) as a starting material for the synthesis of multidentate ligands (Scheme 2). Selenium dioxide gives a high yield in this reaction. Compound (II) was prepared according to the literature $(9,10)$.

Given the similar position of the methyl group in the composition of neocuproine, we thought that selenium would be suitable for the first phase of the reaction (Scheme 2).

All chemicals and solvents used in this study were purchased from Merck (Germany). Melting points (uncorrected) were determined on a Kofler hot-stage. Infrared spectra were obtained using a Shimadzu 470 spectrophotometer (potassium bromide disks). Nuclear magnetic resonance (H-NMR) spectra were recorded using a Varian 500 spectrometer and chemical shifts were reported in parts per million (ppm) relative to that of tetramethylsilane (TMS) as the internal standard. IChemical shift values were given in $\mathrm{d}$ scales. The mass spectra were recorded on LC-MS-Agilent 1100 series and API 2000 LC/MS system. Completion of the reaction was checked by thin layer chromatography

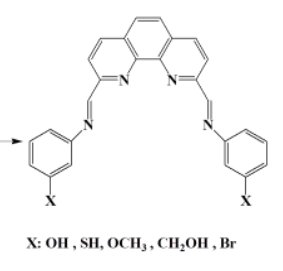

(TLC) on silica gel-coated aluminum sheets (silica gel 60 F254). Commercial grade solvents and reagents were used without further purification.

An equimolar mixture of 1,10-phenanthroline2, 9-dicarbaldehyde (1 mmole) and 3Aminophenol ( 2 mmole) was refluxed in a little acetonitrile for 2 hours. The precipitate was filtered and recrystallized from acetone giving $(3 \mathrm{OH})$ a yield of $90 \%$, m.p:220-222 ${ }^{\circ} \mathrm{C}$. IR $\left(\mathrm{cm}^{-1}\right)$ : 3367(O-H), 3236(Ar-H), 3055(C$\mathrm{H}), \quad 1604 \quad(\mathrm{C}=\mathrm{N}), \quad 1278(\mathrm{C}-\mathrm{O}), \quad{ }^{1} \mathrm{HNMR}$ (5ooMhz, DMSO): $\left[\delta=9.64\left(2 \mathrm{H}_{\mathrm{m}}\right)\right],[\delta=$ $8.92(2 \mathrm{He}),],[\delta=8.79(2 \mathrm{Ha})],[\delta=8.66$ $(2 \mathrm{Hb})],[\delta=8.56(2 \mathrm{Hc})],\left[\delta=8.18\left(2 \mathrm{H}_{\mathrm{h}}\right)\right],[\delta$ $\left.=7.28\left(2 \mathrm{H}_{\mathrm{f}}\right)\right],[\delta=6.92(2 \mathrm{Hg})],[\delta=6.92$ $\left.\left(2 \mathrm{H}_{\mathrm{k}}\right)\right]$.

An equimolar mixture of 1,10-phenanthroline2,9-dicarbaldehyde $(1 \mathrm{mmole})$ and 3aminobenzenethiol ( 2 mmole) was refluxed in a little acetonitrile for 2 hours. The precipitate was filtered and recrystallized from acetone giving (3SH) a yield of $94 \%$, m.p:210-212 ${ }^{\circ} \mathrm{C}$. IR (KBr, vmax, cm-1): 3068(Ar-H), 2807(C$\mathrm{H}), \quad 2684(\mathrm{~S}-\mathrm{H}), \quad 1616(\mathrm{C}=\mathrm{N}), \quad 1508(\mathrm{C}=\mathrm{N})$, 1278(C-O), 1H NMR (500 MHz, DMSO): $[\delta=$ 
$\left.9.72\left(2 \mathrm{H}_{\mathrm{m}}\right)\right],[\delta=8.99(2 \mathrm{He})],,[\delta=8.63($ $2 \mathrm{Ha})],\left[\delta=8.53\left(2 \mathrm{H}_{\mathrm{b}}\right)\right],[\delta=8.12(2 \mathrm{Hc})],[\delta=$ $\left.7.46\left(2 \mathrm{H}_{\mathrm{h}},\right)\right], \quad\left[\delta=7.44\left(2 \mathrm{H}_{\mathrm{f}}\right)\right], \quad[\delta=6.89$ $(2 \mathrm{Hg})],\left[\delta=6.87\left(2 \mathrm{H}_{\mathrm{k}}\right)\right]$.

An equimolar mixture of 1,10-phenanthroline2,9-dicarbaldehyde (1 mmole) and 3methoxybenzenamine $(2 \mathrm{mmole})$ was refluxed in a little acetonitrile for 2 hours. The precipitate was filtered and recrystallized from acetone giving $(3 \mathrm{M})$ a yield of $85 \%$, m.p:185$188{ }^{\circ} \mathrm{C}$. IR (KBr, vmax, $\left.\mathrm{cm}^{-1}\right)$ : 2998(Ar-H), 2902( $\mathrm{Ar}-\mathrm{H}), \quad 1579(-\mathrm{C}=\mathrm{N}), \quad 1504(-\mathrm{C}=\mathrm{N})$, 1288(Ar-O), 1247( Ar-O-CH $)$, 1033(-O- $\left.\mathrm{CH}_{3}\right)$, 869(Ar-H), ${ }^{1} \mathrm{H}$ NMR (500 MHz, DMSO): $[\delta=$ $9,02(2 \mathrm{He})],[\delta=8.66(\mathrm{H})],[\delta=8.56$ $\left.\left(2 \mathrm{H}_{\mathrm{b}}\right)\right],[\delta=8.15(2 \mathrm{Hc})],\left[\delta=7.56\left(2 \mathrm{H}_{\mathrm{h}}\right)\right],[\delta=$ $\left.7.55\left(2 \mathrm{H}_{\mathrm{f}}\right)\right],[\delta=7.54(2 \mathrm{Hg})],\left[\delta=7.54\left(2 \mathrm{H}_{\mathrm{k}}\right)\right]$ , $\left[\delta=7.06\left(3 \mathrm{H}_{\mathrm{m}}\right)\right]$.

An equimolar mixture of 1, 10-phenanthroline2,9-dicarbaldehyde (1mmole) and 3-bromobenzenamine $(2 \mathrm{mmole})$ was refluxed in a little acetonitrile for 2 hours. The precipitate was filtered and recrystallized from acetone giving $(3 \mathrm{Br})$ a yield of $80 \%$, m.p: $225-228{ }^{\circ} \mathrm{C}$. IR (KBr, vmax, $\left.\mathrm{cm}^{-1}\right)$ : 3411(Ar-H), 1621($\mathrm{C}=\mathrm{N}), \quad 1581(-\mathrm{C}=\mathrm{N}), \quad 1498(\mathrm{C}-\mathrm{C}) \mathrm{Ar}, 1085(\mathrm{C}-$ $\mathrm{Br}), 856(\mathrm{Ar}-\mathrm{H}) .{ }^{1} \mathrm{H}$ NMR (500 MHz, DMSO): $[\delta=8.98(2 \mathrm{He})],[\delta=8.70(2 \mathrm{Ha})],[\delta=8.57$ $\left.\left(2 \mathrm{H}_{\mathrm{b}}\right)\right],[\delta=8.12(2 \mathrm{Hc})],\left[\delta=7.67\left(2 \mathrm{H}_{\mathrm{h}},\right)\right],[\delta=$ $\left.7.54\left(2 \mathrm{H}_{\mathrm{f}}\right)\right],[\delta=7.49(2 \mathrm{Hg})],\left[\delta=7.45\left(2 \mathrm{H}_{\mathrm{k}}\right)\right]$. An equimolar mixture of 1,10-phenanthroline- 2,9-dicarbaldehyde (1mmole) and 4Aminobenzyl alcohol (2 mmole) was refluxed in a little acetonitrile for 2 hours. The precipitate was filtered and recrystallized from acetone giving (3Ben) a yield of $90 \%$, m.p:175-178 ${ }^{\circ} \mathrm{C}$. IR (KBr, vmax, $\mathrm{cm}^{-1}$ ): 3378(O-H), 3056(Ar-H), 1498(-C=N), 1467($\mathrm{C}=\mathrm{N}), \quad 856(\mathrm{Ar}-\mathrm{H}),{ }^{1} \mathrm{H} \quad \mathrm{NMR} \quad(500 \mathrm{MHz}$, DMSO): $\left[\delta=8.91\left(2 \mathrm{H}_{\mathrm{m}}\right)\right],[\delta=8.67(2 \mathrm{He})$,$] ,$ $[\delta=8.56(2 \mathrm{Ha})],\left[\delta=8.10\left(2 \mathrm{H}_{\mathrm{b}}\right)\right],[\delta=7.46$ $(2 \mathrm{Hc})],\left[\delta=7.40\left(2 \mathrm{H}_{\mathrm{h}}\right)\right],\left[\delta=7.38\left(2 \mathrm{H}_{\mathrm{f}}\right)\right],[\delta$ $=7.33(2 \mathrm{Hg})],\left[\delta=7.31\left(2 \mathrm{H}_{\mathrm{k}}\right)\right], \quad[\delta=4.59$ $\left.\left(4 \mathrm{H}_{1}\right)\right]$. All the newly synthesized compounds were screened for antibacterial activity against Staphylococcus aureus, Escherichia coli and Pseudomonas aeruginosa by determining minimal inhibitory concentration (MIC) and minimal bactericidal concertation (MBC) using the ذroth dilution method $(3,11)$. Several colonies of $S$. aureus, $E$. coli and $P$. aeruginosa were taken from fresh cultures and inoculated in separate tubes containing $5 \mathrm{~mL}$ of trypticase soy broth. The tubes were incubated at $37^{\circ} \mathrm{C}$ for 6 hours until achieving visible growth. Turbidity was adjusted to 0.5 McFarland Standard by adding $0.05 \mathrm{~mL}$ of $1 \%$ w/v $\mathrm{BaCl}_{2} \cdot 2 \mathrm{H}_{2} \mathrm{O}$ in phosphate buffered saline (PBS) to $9.95 \mathrm{~mL}$ of $1 \% \mathrm{v} / \mathrm{v} \mathrm{H}_{2} \mathrm{SO}_{4}$ in PBS. Finally, $10 \mathrm{mg}$ of each compound were dissolved in $10 \mathrm{~mL}$ of dimethylformamide to obtain concentration of $1 \mathrm{mg} / \mathrm{mL}$.

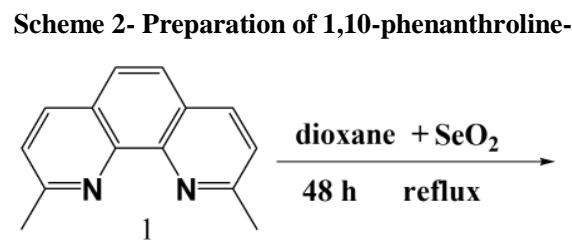

2,9-dimethyl-1,10-phenanthroline

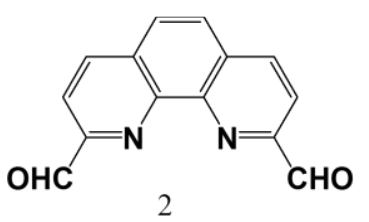

1,10-phenanthroline-2,9-dicarbaldehyde

\section{RESULTS}

Chemical structure of some of the most important derivatives are shown in scheme 3 .
The results of the MBC and MIC assays are reported in Table 1.

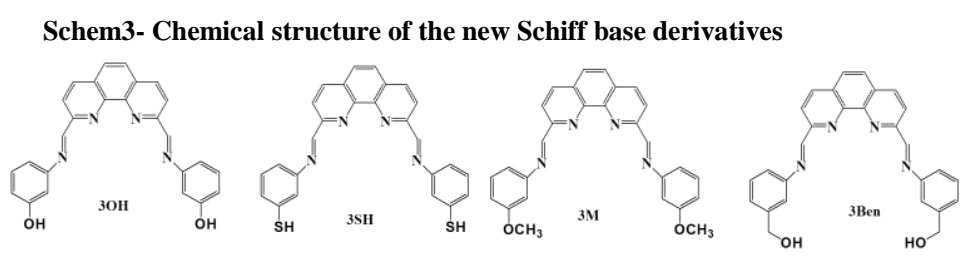


Table 1-The MIC and MBC of the synthesized Schiff bases against the tested bacteria

\begin{tabular}{|c|c|c|c|c|c|c|}
\hline Bacterium & Concentration (mg/ml) & 3ЕОH & 3ESH & 3M & $3 \mathrm{Br}$ & 3AB \\
\hline \multirow[t]{8}{*}{$P$. aeruginosa } & 0.5 & - & - & - & - & - \\
\hline & 0.25 & - & - & - & - & - \\
\hline & 0.125 & - & - & - & - & - \\
\hline & 0.0625 & + & - & + & - & + \\
\hline & 0.031 & + & + & + & + & + \\
\hline & 0.016 & + & + & + & + & + \\
\hline & MIC & 0.125 & 0.0625 & 0.0625 & 0.125 & 0.125 \\
\hline & MBC & 0.125 & 0.125 & 0.25 & 0.125 & 0.125 \\
\hline \multirow[t]{8}{*}{ E. coli } & 0.5 & - & - & - & - & - \\
\hline & 0.25 & - & - & - & - & - \\
\hline & 0.125 & - & - & - & - & - \\
\hline & 0.0625 & + & - & + & - & - \\
\hline & 0.031 & + & + & + & + & + \\
\hline & 0.016 & + & + & + & + & + \\
\hline & MIC & 0.125 & 0.0625 & 0.0625 & 0.125 & 0.125 \\
\hline & MBC & 0.125 & 0.0625 & 0.5 & 0.0625 & 0.125 \\
\hline \multirow[t]{8}{*}{ S. aureus } & 0.5 & - & - & - & - & - \\
\hline & 0.25 & - & - & - & - & - \\
\hline & 0.125 & - & - & - & - & - \\
\hline & 0.0625 & + & - & + & - & + \\
\hline & 0.031 & + & + & + & + & + \\
\hline & 0.016 & + & + & + & + & + \\
\hline & MIC & 0.125 & 0.0625 & 0.0625 & 0.125 & 0.125 \\
\hline & MBC & 0.25 & 0.25 & 0.25 & 0.125 & 0.25 \\
\hline
\end{tabular}

$\mathrm{MIC}$ and $\mathrm{MBC}$ are reported in $\mathrm{mM}$.

\section{DISCUSSION}

All the synthesized compounds were tested against one gram-positive and two gram-negative strains of bacteria. Among the tested compounds, compound 2ESH showed good MIC, and compounds $3 \mathrm{EOH}$ and $3 \mathrm{ESH}$ showed moderate to good antibacterial activity. All synthesized compounds exhibited favorable antibacterial effect against $S$. aureus. However, given the smaller MIC and MBC values, compound $4 \mathrm{EOH}$ showed the highest antibacterial activity against $S$. aureus. Although all synthesized compounds had relatively favorable effects against E. coli, this effect was more significant in the case of compound 2ESH. Given the results of the MBC and MIC assay, all synthesized compounds had good antibacterial effects against $P$. aeruginosa, but the activity of compounds $3 \mathrm{ESH}$ and $3 \mathrm{EOH}$ against

this bacterium were more profound.

\section{CONCLUSION}

The results show that compound $3 \mathrm{EOH}$ has the highest inhibitory and bactericidal
Effects against the gram-negative bacteria, while compounds $3 \mathrm{EOH}, 3 \mathrm{ESH}$ and $3 \mathrm{M}$ have equal inhibitory and bactericidal effects against $P$. aeruginosa, $E$. coli and $S$. aureus.

In addition, compound $3 \mathrm{EOH}$ has a relatively better MIC and MBC values against the tested bacteria.

\section{ACKNOWLEDGMENTS}

We would like to thank the Islamic Azad University, Gorgan branch for the financial support.

We also gratefully acknowledge the staff of NMR Laboratory and Spectroscopy Laboratory at University of Tehran as well as the Department of Microbiology at Islamic Azad University, Gorgan branch for their contribution to this study.

\section{CONFLICT OF INTEREST}

The authors declare that there is no conflict of interest regarding the publication of this article. 


\section{REFERENCES}

1. Cleiton M da Silva, Daniel L da Silva, Luzia V Modolo , Rosemeire B Alves, Maria A de Resende, Cleide VB Martins. Schiff bases: A short review of their antimicrobial activities. Journal of Advanced Research. 2011; 2(1): 1-8. DOI: 10.4236/abc.2013.35051.

2. Meenachi M, Chitra S. Review of Chemistry and Biological Importance of Schiff Base. International Journal of Scientific Research and Reviews. 2014; 3(1): 8-18.

3. Malladi S, Isloor AM, Isloor S, Akhila DS, Fun HK. Synthesis, Characterization and Antibacterial activity of some new pyrazole based Schiff bases. Arabian Journal of Chemistry. 2013; 6(3): 335-40.

4. Vijesh AM, Isloor AM, Prabhu V, Ahmad S, Malladi, S. Synthesis, characterization and anti-microbial studies of some novel 2,4-disubstituted thiazoles. Eur Journal Med Chem. 2010; 45(11): 5460-4.

5. Schiff H. Mittheilungen aus dem universita. tslaboratorium in Pisa: Eine neue reihe organischer basen. Justus Liebigs Ann Chem. 1864; 131(1): 118-9.

6. Holla BS, Veerendra B, Shivananda MK, Poojary, B. Synthesis characterization and anticancer activity studies on some Mannich bases derived from 1,2,4-triazoles. Eur Journal Med Chem. 2003; 38(7-8): 759-67.
7. Patole J, Shingnapurkar D, Padhye S, Ratledge C. Schiff base conjugates of p-aminosalicylic acid as antimycobacterial agents. Bioorganic \& Medicinal Chemistry Letters. 2006; 16(6): 1514-7.

8. Shi L, Ge HM, Tan SH, Li HQ, Song YC, Zhu HL, et al. Synthesis and antimicrobial activities of Schiff bases derived from 5-chloro-salicylaldehyde. Eur J Med Chem. 2007; 42(4): 558-64.

9. Chandler CJ, Deady LW, Reiss JA. Synthesis of some 2,9-disubstitued- 1,10- phenanthrolines. Journal Hetrocyclic Chem. 1981; 18: 599-601.

10. Habibi M, Bayat Y, Marandi R, Mehrdadsharif AA, Salahi A. One-pot Synthesis of 4H-Pyran-4-one Carboxaldehyde Derivatives by Using Selenium Dioxide as a Reusable Oxidant. Asian Journal of chemistry. 2012; 24(11): 5239-41.

11. Collee J. Mackie and Mccartney Practical Medical Microbiology. $13^{\text {th }}$ ed.Churchill Livingstone. Edinburgh. 1989. 